\title{
BEBERAPA FAKTOR YANG BERPENGARUH TERHADAP MOTIVASI BELAJAR MAHASISWA PERGURUAN TINGGI SWASTA (PTS) (STUDI KASUS PADA MAHASISWA FAKULTAS EKONOMI DI KOTA PALEMBANG)
}

\author{
Oleh: \\ Dwi Eka Novianty ${ }^{1),}$ Junaidi $^{2)}$ \\ ${ }^{1)}$ Fakultas Ekonomi Universitas IBA Palembang \\ Jalan Mayor Ruslan Palembang \\ ${ }^{2)}$ STIE Abdi Nusa Palembang \\ Jalan Veteran Palembang
}

\begin{abstract}
This study aims to determine the effect of student conditions, skills of lecturers teaching and campus environment on student learning motivation Faculty Economics of PTS. The data were collected from August - September 2017. The data used were secondary data from questionnaires distributed to several PTS campuses in Palembang, Palembang University, Tridinanti University, IBA University and Muhammadiyah University of Palembang. There were 260 questionnaires distributed, from which the questionnaire was then tabulated, then the statistical test using SPSS obtained the following results: 1) The result of multiple linear analysis showed that all independent variables (student condition, teaching skill of lecturer and campus environment) had significant influence to student's learning motivation, student condition variable have more dominant influence than other variable, 2) result of t test indicate that partially variable of student condition and campus environment have significant effect to student's motivation variable, while partial teaching skill has no significant effect to student's learning motivation 3) F Test Result indicate that student condition variable, teaching skill of lecturer and campus environment simultaneously / simultaneously have an effect on student's motivation variable, 4) Adjusted $R R$ Test Result are showing the coefficient of determination equal to 0,307 or 30,7\% variable of student condition, teaching skill of lecturer and campus environment influence student learning motivation.
\end{abstract}

\section{Keywords: Student Condition, Teaching Lecturer Skills, Campus Environment, Student Motivation}

\begin{abstract}
ABSTRAK
Penelitian ini bertujuan untuk mengetahui pengaruh kondisi mahasiswa, keterampilan dosen mengajar dan lingkungan kampus terhadap motivasi belajar mahasiswa Fakultas Ekonomi PTS. Pengambilan data dilakukan pada periode bulan Agustus - September 2017. Data yang digunakan berupa data sekunder dari kuesioner yang disebarkan pada beberapa kampus PTS di kota Palembang yaitu Universitas Palembang, Universitas Tridinanti, Universitas IBA dan Universitas Muhammadiyah Palembang. Terdapat 260 koesioner yang disebarkan, dimana dari jawaban kuesioner tersebut dilakukan tabulasi, kemudian dilakukan uji statistik dengan menggunakan SPSS diperoleh hasil sebagai berikut: 1) hasil analisis linier berganda menunjukkan semua
\end{abstract}


variabel independen (kondisi mahasiswa, keterampilan mengajar dosen dan lingkungan kampus) berpengaruh secara signifikan terhadap motivasi belajar mahasiswa, variabel kondisi mahasiswa berpengaruh lebih dominan dibandingkan variabel lain, 2) hasil uji $t$ menunjukkan bahwa secara parsial variabel kondisi mahasiswa dan lingkungan kampus berpengaruh secara signifikan terhadap variabel motivasi belajar ,mahasiswa,sedangkan keterampilan mengajar dosen secara parsial tidak berpengaruh secara signifikan terhadap motivasi belajar mahasiswa 3) Hasil Uji F menunjukkan bahwa variable kondisi mahasiswa, keterampilan mengajar dosen dan lingkungan kampus secara simultan/serempak berpengaruh terhadap variabel motivasi belajar mahasiswa, 4) Hasil Uji Adjusted $R$ square menunjukkan koefisien determinasi sebesar 0,307 atau 30,7\% variabel kondisi mahasiswa, keterampilan mengajar dosen dan lingkungan kampus mempengaruhi motivasi blajar mahasiswa.

\section{Kata kunci: Kondisi Mahasiswa, Keterampilan Dosen Mengajar, Lingkungan Kampus, Motivasi Belajar Mahasiswa}

\section{LATAR BELAKANG}

Belajar merupakan suatu proses yang tidak dapat di lepaskan dari kehidupan manusia. Belajar merupakan sebuah infestasi masa depan, artinya kesuksesan manusia tidak akan pernah di dapatkan tanpa melalui proses belajar, karena di dalam belajar inilah manusia menemukan pengetahuan dan pengalaman yang baru. Manusia mengalami perubahan akibat kegiatan belajarnya. Proses pengembangan melalui belajar pada hakikatnya adalah merupakan proses aktualisasi potensi pengetahuan manusia yang telah ada dalam dirinya. Belajar atau proses perubahan tingkah laku yang terjadi dipengaruhi oleh dua faktor,yaitu factor internal dan factor eksternal.

Seorang mahasiswa dalam melakukan aktivitas belajar memerlukan adanya dorongan tertentu agar kegiatan belajarnya dapat menghasilkan prestasibelajaryang sesuai dengan tujuan yang diharapkan. Untuk dapat meningkatkan prestasi belajar mahasiswa yang maksimal, tentunya perlu diperhatikan berbagai faktor yang membangkitkan mahasiswa untuk belajar dengan efektif. Salah satu faktor penyebab yang mempengaruhinya adalah motivasi belajar. Dalam belajar, motivasi memegang peranan penting. Motivasi yang dimiliki mahasiswa akan menentukan hasil yang dicapai dari aktivitas pembelajaran.

Motivasi belajar merupakan kondisi psikis yang dapat mendorong seseorang untuk 
belajar. Besarnya motivasi setiap mahasiswa dalam belajar berbeda - beda. Tinggi rendahnya motivasi belajar mahasiswa tergantung pada faktor-faktor dari mahasiswa itu sendiri (intrinsik) dan motivasi yang berasal dari luar (ekstrinsik).

Mahasiswa yang kuliah di Perguruan Tinggi Swasta (PTS) memiliki motivasi yang berbeda-beda lebih beragam daripada yang kuliah di Perguruan Tinggi Negeri. Hal ini dikarenakan mahasiswa PTS memiliki latar belakang yang beragam baik dari segi umur, pengalaman, keluarga, pekerjaan dan lainnya. Mahasiswa yang telah bekerja dan memiliki tanggung jawab keluarga tentunya berbeda motivasinya dengan mahasiswa yang fresh graduate dan belum memiliki tanggung jawab dalam keluarga.

Motivasi belajar bisa naik turun, ini tentu ada faktor yang melatar belakangi timbulny amasalah tersebut, diantaranya yaitu faktor mahasiswa itu sendiri (internal) dan dari luarmahasiswa (eksternal). Kedua faktor tersebut merupakan fenomena yang tidak dapat dilepaskan dalam proses belajar, sehingga menarik untuk diteliti pengaruh kedua faktor tersebut terhadap motivasibelajar mahasiswa di PTS. Dalam penelitian ini dibatasi hanya pada mahasiswa yang kuliah di Fakultas Ekonomi yang ada di kota Palembang.

Faktor mahasiswa itu sendiri (internal) berasal dari kondisi fisik dan kondisi mental. Yang dimaksud dengan kondisi fisik di sini adalah kondisi mahasiswa sehat, atau mengalami gangguan sakit yang dapat menurunkan motivasi belajar. Sedangkan kondisi mental adalah kondisi mahasiswa yang dipengaruhi oleh masalah keluarga, masalah pekerjaan, masalah hubungan dengan teman/ dosen dan lainnya.

Faktor eksternal berasal dari luar individu mahasiswa / lingkungan, faktor ini mempunyai hubungan erat dengan kondisi psikologis mahasiswa selaku makhluk social yang tidak dapat terlepas dari kehidupan social maupun non-sosial. Faktor eksternal dilihat dari segi sosial yaitui nteraksi manusia dengan manusia lainnya, seperti interaksi mahasiswa dengan dosen, sesame mahasiswa, dan lain sebagainya. Pengaruh teman lebih mendominasi saat pelaksanaan perkuliahan, seperti provokasi bolos kuliah, mengerjakan tugas bila bersama-sama teman.Minim nya jam terbuka antara mahasiswa dengan dosen yang berpengaruh terhadap kedekatan / keakraban antara mahasiswa dengan dosen. Ini tentu mempunyai dampak yang tidak baik terhadap proses pembelajaran, karena akan timbul sekat antara mahasiswa dengan dosen yang menutup keterbukaan dalam pengembangan keilmuan. 
Sebagai fasilitator di dalam kelas, seorang Dosen harus mampu mengelola seluruh proses kegiatan belajar-mengajar dengan menciptakan kondisi belajar yang nyaman sehingga setiap mahasiswa dapat belajar secara efektif dan efisien. Oleh karena itu, dosen harus menguasai keterampilan mengajar yang baik. Secara sederhana dapat dikatakan apabila mahasiswa tidak memiliki motivasi belajar maka tidak akan terjadi kegiatan belajar pada diri mahasiswa tersebut. Apabila motivasi rendah, umumnya diasumsikan bahwa prestasi yang bersangkutan akan rendah dan besar kemungkinan ia tidak akan mencapai tujuan belajar. Menjadi pendidik yang professional, seorang dosen harus bertanggung jawab terhadap segala tindakannya dalam pembelajaran di kampus, dan dalam kehidupan bermasyarakat, untuk itu seorang dosen harus memiliki keterampilan mengajar yang kreatif dan inovatif. Dalam hal ini tentunya Dosen dituntut untuk memiliki keterampilan dasar dalam mengajar untuk menunjang kegiatan pembelajaran.

Selain keterampilan mengajar dosen, faktor lain yang menentukan motivasi belajar mahasiswa adalah lingkungan kampus. Secara sadar atau tidak, individu senantiasa terpengaruh oleh lingkungannya. Lingkungan kampus merupakan situasi yang turut serta mempengaruhi kegiatan belajar mahasiswa.Sebagai contoh, kondisi lingkungan kampus yang kondusif akan menciptakan ketenangan dan kenyamanan mahasiswa dalam belajar, sehingga mahasiswa akan lebih mudah untuk menguasai materi belajar secara maksimal dan lebih termotivasi belajarnya. Lingkungan kampus yang kondusif meliputi hubungan yang baik antara sesama mahasiswa serta hubungan antara mahasiswa dengan dosen, tersedianya perpustakaan yang lengkap, kemudahan akses internet, ruang kelas yang bersih dan nyaman. Lingkungan kampus yang kondusif dapat mempengaruhi prestasi belajar mahasiswa. Lingkungan yang tidak sehat akan membuat mahasiswa merasa stress sehingga berdampak pada menurunnya motivasi belajar mahasiswa yang pada akhirnya dapat mempengaruhi prestasi belajarnya.

Berdasarkan fenomena di atas peneliti tertarik untuk meneliti lebih jauh tentang:

1. Bagaimana pengaruh kondisi mahasiswa terhadap motivasi belajar?

2. Bagaimana pengaruh keterampilan mengajar dosen terhadap motivasi belajar?

3. Bagaimana pengaruh lingkungan kampus terhadap motivasi belajar?

4. Bagaimana pengaruh kondisi mahasiswa, keterampilan mengajar dosen dan lingkungan kampus secara simultan terhadap motivasi belajar? 


\section{KAJIAN TEORITIS}

\section{Motivasi Belajar}

Mulyasa (2004: 112) mengemukakan mengenai pengertian motivasi: Motivasi adalah tenaga pendorong atau penarik yang menyebabkan adanya tingkah laku ke arah suatu tujuan tertentu. Peserta didik akan bersungguh-sungguh karena memiliki motivasi yang tinggi.Seorang mahasiswa akan belajar bila ada faktor pendorongnya yang disebut motivasi. Jadi dapat dikatakan bahwa motivasi belajar adalah keseluruhan daya penggerak di dalam diri seseorang yang menimbulkan kegiatan dan memberikan arah, sehingga tujuan yang dikehendaki dapat tercapai. Dalam motivasi belajar dorongan merupakan kekuatan mental untuk melakukan kegiatan dalam rangka pemenuhan harapan dan dorongan dalam hal ini adalah pencapaian tujuan.

Menurut Hakim(2010:6)secara garis besar, faktor-faktor yang mempengaruhi motivasi itu dapat dibagi menjadi dua bagian, yaitu faktor internal dan eksternal. Faktor internal merupakan factor yang terdapat didalam diri individu itu sendiri, seperti kesehatan jasmani dan rohani, kecerdasan (intelegensia), daya ingat, kemauan, dan bakat. Faktor eksternal merupakan faktor yang terdapat diluar diri individu yang bersangkutan, seperti keadaan lingkungan rumah, sekolah, masyarakat,dan segala sesuatu yang berhubungan dengan lingkungan tersebut.

\section{Kondisi Mahasiswa}

Kondisi siswa (dalam penelitian ini adalah mahasiswa) adalah kondisi yang meliputi kondisi-kondisi jasmani dan rohani yang mempengaruhi motivasi belajar. Misalnya seorang siswa yang sedang sakit akan mempengaruhi perhatian belajar, sebaliknya seorang siswa yang sehat akan mudah memusatkan perhatian. Dengan kata lain, kondisi jasmani dan rohani siswa berpengaruh pada motivasi belajar (Dimyati dan Mudjiono, 2006:97). Kondisi siswa memiliki ciri - ciri yang khas, yaitu bukan hanya bersifat jasmaniah (fisik) tetapijuga ciri-ciri rohaniah (psikis). Aspekj asmani meliputi tinggi dan besar badan, panca indra, anggota badan dan lainnya. Aspek rohani meliputi kecerdasan, bakat, kecakapan hasil belajar, sikap, watak, kemampuan social dan lainnya (Sukmadinata, 2007:35-36). 
Dari definisi di atas, perlu dijelaskan bahwa yang dimaksud dengan kesehatan jasmani dan rohani. Kesehatan jasmani ialah keadaan baik, artinya bebas dari sakit seluruh badan serta bagian - bagiannya. Maka dia dapat dengan mudah mengikuti semua aktivitas pembelajaran baik di sekolah maupun dalam lingkungan masyarakat. Sedangkan yang dimaksud dengan kesehatan rohani ialah kemampuan menyesuaikan diri terhadap berbagai tuntutan perkembangan sesuai usianya, baik tuntutan dalam diri sendiri maupun dari luar dirinya sendiri, seperti menyesuaikan diri dengan lingkungan rumah, sekolah, dan lingkungan masyarakat. Seorang mahasiswa akan dapat mengikuti pelajaran dengan baik bila dia sehat secara rohani (mental), rasa tersebut meliputi rasa aman, kasih sayang, kebahagiaan dan rasa diterima oleh teman-temannya. Begitu pula sebaliknya, bila kondisi rohani tidak sehat, makamahasiswa tersebut akan merasakan adanya rasa cemas, sedih, marah, kesal, khawatir, rendah diri, kurang percaya diri dan lain sebagainya.

\section{Keterampilan Mengajar Dosen}

Undang-Undang Sistem Pendidikan Nasional Tahun 2003 Bab XI pasal 39 menjelaskan: "Pendidik merupakan tenaga profesional yang bertugas merencanakan dan melaksanakan proses pembelajaran, menilai hasil pembelajaran, melakukan pembimbingan dan pelatihan, serta melakukan penelitian dan pengabdian kepada masyarakat, terutama bagi pendidik pada perguruan tinggi:. Menjadi pendidik yang professional seorang dosen harus bertanggung jawab terhadap segala tindakannya dalam pembelajaran di perguruan tinggi, dan dalam kehidupan bermasyarakat, untuk itu seorang dosen harus memiliki keterampilan mengajar yang kreatif dan inovatif.

Djamarah (2010:89) menyatakan keterampilan mengajar adalah "keterampilan yang mutlak harus dimiliki oleh pendidik dalam menjalankan tugasnya dalam interaksi edukatif di dalam kelas". Sedangkan menurut Sardiman (2011:193) keterampilan mengajar adalah "keterampilan yang dibutuhkan dalam berbagai pelaksanaan peran seorang pendidik di dalam kelas".

Dari beberapa penjelasan para ahli di atas maka dapat disimpulkan bahwa keterampilan mengajar dosen adalah seperangkat kemampuan/kecakapan yang harus dikuasai oleh dosen dalam melaksanakan peranannya di dalam kelas. Terdapat 8 
(delapan) keterampilan mengajar yang mutlak harus dikuasai oleh seorang pengajar (Djamarah, 2010:99)

1. Keterampilan Bertanya

2. Keterampilan Memberi Penguatan (reinforcement)

3. Keterampilan Mengadakan Variasi

4. Keterampilan Menjelaskan

5. Keterampilan Membuka dan Menutup Pelajaran

6. Keterampilam Membimbing Diskusi Kelompok Kecil

7. Keterampilan Mengelola Kelas

8. Keterampilan Mengajar Kelompok Kecil dan Perorangan

\section{Lingkungan Kampus}

Hamalik (2003:195) menyatakan lingkungan adalah: "segala sesuatu yang ada di alam sekitar yang memiliki makna atau pengaruh tertentu kepada individu". Menurut Ginting (2013:110) kampus adalah "lingkungan sosial dan lingkungan pendidikan". Hastuti (2010:88) menyatakan bahwa lingkungan kampus merupakan "tempat seorang mahasiswa dalam menjalankan kegiatan-kegiatan pendidikan dan melakukan aktifitas untuk memperoleh ilmu pengetahuan, perubahan sikap, dan keterampilan hidup baik di dalam kelas maupun di luar kelas dengan mengikuti dan menaati peraturan dalam sistematika pendidikan yang telah ditetapkan".

Indikator-indikator yang dapat digunakan untuk mengukur pengaruh lingkungan kampus terhadap motivasi belajar menurut Hastuti (2010:95) yaitu :
a. Ukuran kelas
b. Tata letak kampus
c. Kebersihan kampus
d. Fasilitas internet
e. Fasilitas perpustakaan
f. Suhu udara
g. Tingkat kebisingan
h. Hubungan antar mahasiswa
i. Hubungan mahasiswa dengan dosen

\section{METODE PENELITIAN}

Penelitian dilakukan dalam bentuk penelitian deskriptif dan verifikatif. Penelitian deskriptif dilakukan untuk mendapatkan gambaran tentang variabel-variabel yang mempengaruhi motivasi belajar mahasiswa PTS. Penelitian verifikatif digunakan untuk 
menguji hipotesis dengan menggunakan perhitungan statistik. Karena jenis penelitian ini meliputi penelitian deskriptif dan verifikatif yang dilaksanakan melalui pengumpulan data di lapangan dengan menggunakan kuesioner sebagai alat pengumpul data utama, maka metode penelitian yang digunakan adalah desktiptive survey dan explanatory survey.

Populasi dalam penelitian ini adalah mahasiswa yang kuliah di Fakultas Ekonomi pada Perguruan Tinggi Swasta (PTS) di kota Palembang. Pemilihan PTS didasarkan kepada usia Fakultas Ekonomi $\geq 30$ tahun, sehingga terpilih Fakultas Ekonomi Universitas Palembang, Universitas Tridinanti, Universitas IBA dan Universitas Muhammadiyah Palembang. Jumlah populasi sebanyak 6.890 mahasiswa. Data diambil adalah jumlah mahasiswa yang dilaporkan oleh PTS yang bersangkutan untuk tahun 2016/2017 pada forlap ristekdikti.go.id..Penentuan ukuran sampel berdasarkan rumus slovin dengan taraf kesalahan 10\% sehingga diperoleh jumlah sampel sebanyak 260. Teknik penarikan sampel menggunakan non probability sampling dimana pengambilan sampel dilakukan secara aksidental dengan alasan kemudahan dalam pengambilan data bila dipandang orang yang ditemui itu cocok sebagai sumber data.

Pengumpulan data dalam penelitian ini menggunakan wawancara melalui instrumen daftar pertanyaan/kuesioner. Jawaban atas pertanyaan-pertanyaan dalam daftar kuesioner disusun berdasarkan skala likert.

Data yang telah dikumpulkan kemudian diolah agar memiliki makna untuk memecahkan masalah yang diteliti. Kemudian dilakukan pengujian validitas instrumen penelitian dengan cara melihat validasi konten terhadap indikator-indikatornya sehingga semua konsep yang ingin diukur diuji dengan menggunakan uji korelasi Pearson. Sedangkan pengujian reliabilitasnya dengan menggunakan metode spearman rho correlation, dengan cara menggunakan SPSS.

Model kerangka pemikiran dikembangkan untuk mengetahui faktor-faktor yang secara langsung maupun tidak langsung mempengaruhi motivasi belajar mahasiswa. Faktor-faktor tersebut adalah kondisi mahasiswa, keterampilan dosen mengajar dan lingkungan kampus. Berdasarkan rumusan masalah, tujuan penelitian dan landasan teori dapat disusun kerangka pemikiran yang berfungsi sebagai penuntun alur pikir sekaligus sebagai dasar dalam penelitian ini seperti pada Gambar 1 berikut ini. 


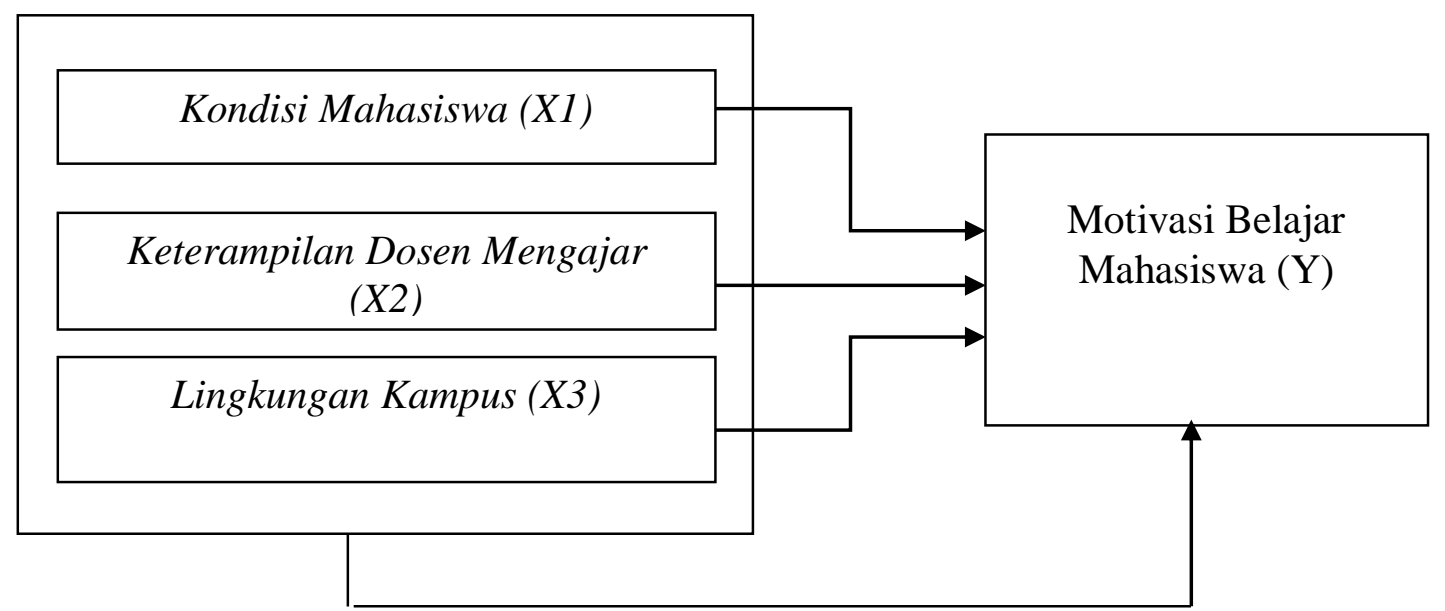

Gambar 1. Kerangka Berfikir

Dari kerangka berfikir di atas dapat dijelaskan indikator-indikator dari masingmasing variabel.

Indikator dari kondisi mahasiswa adalah:

1. kondisi fisik

2. kondisi psikologis

Indikator Keterampilan dosen mengajar adalah:

1. Keterampilan bertanya,

2.Keterampilan memberikan Penguatan

3. Keterampilan mengadakan variasi

4. Keterampilan menjelaskan

5. Keterampilan membuka dan menutup pelajaran

6. Keterampilan membimbing diskusi kelompok kecil

7. Keterampilan mengelola kelas

8. Keterampilan mengajar kelompok kecil dan perorangan

Indikator Lingkungan Kampus adalah:

1. Ukuran kelas

2. Tata letak kampus

3. Kebersihan kampus

4. Fasilitas internet

5. Fasilitas perpustakaan

6. Suhu udara

7. Tingkat kebisingan

8. Hubungan antar mahasiswa

9. Hubungan mahasiswa dengan dosen

Indikator Motivasi belajar mahasiswa adalah

1. Memilikikeinginandalam belajar/inisiatif untuk belajar 
2. Memilikisemangatbelajar yangkuat

3. Rajindalambelajar

4. Tidakpernahpuasdengan hasilbelajaryangdicapai

5. Perhatianterhadap pembelajaran

6. Aktifdalambertanya

Teknik analisis yang digunakan dalam penelitian ini adalah analisis regresi linier Berganda. Regresi linier berganda digunakan untuk menentukan pengaruh antara satu variabel dengan beberapa variabel lainnya yang dinyatakan dengan persamaan regresi. Analisis ini digunakan untuk melihat pengaruh kondisi mahasiswa, keterampilan dosen mengajar dan lingkungan kampus terhadap motivasi belajar mahasiswa PTS.

Rumus yang digunakan adalah:

$$
\mathrm{Y}=\mathrm{a}+\mathrm{b}_{1} \mathrm{X}_{1}+\mathrm{b}_{2} \mathrm{X}_{2}+\mathrm{b}_{3} \mathrm{X}_{3}+\ldots . .+€(\text { Sugiyono,2003). }
$$

Dimana :

$$
\begin{aligned}
& Y=\text { Motivasi Belajar Mahasiswa } \\
& a=\text { Nilai Konstanta } \\
& b=\text { Koefisien Regresi } \\
& X_{1}=\text { Kondisi Mahasiswa } \\
& X_{2}=\text { Keterampilan Dosen Mengajar } \\
& X_{3}=\text { Lingkungan Kampus } \\
& €=\text { error }
\end{aligned}
$$

\section{HASIL PENELITIAN DAN PEMBAHASAN}

\section{Statistik Deskriptif Responden}

Berdasarkan data yang diperoleh dari forlap ristekdikti.go.id untuk tahun 2016/2017, jumlah mahasiswa Fakultas Ekonomi Universitas Palembang berjumlah 264 orang, mahasiswa Fakultas Ekonomi Universitas Tridinanti berjumlah 3.142 orang, mahasiswa Fakultas Ekonomi Universitas IBA berjumlah 463 orang dan mahasiswa Fakultas Ekonomi Universitas Muhammadiyah Palembang berjumlah 3.021 orang. Total jumlah mahasiswa yang menjadi populasi sebanyak 6.890 orang. Dengan menggunakan 
rumus slovin pada taraf kesalahan 10\% diperoleh angka 260 yang dijadikan sebagai jumlah sampel penelitian.

Dari jumlah kuesioner yang terkumpul diperoleh statistik deskriptif responden sebagai berikut:

\section{Tabel 1. Statistik Deskriptif Responden}

\begin{tabular}{lrl}
\hline Keterangan & Jumlah & Persentase \\
\hline Jenis Kelamin & & \\
Wanita & 169 orang & $65 \%$ \\
Pria & 91 orang & $35 \%$ \\
\hline Total & 260 orang & $100 \%$ \\
\hline Status & & \\
Bekerja & 197 orang & $76 \%$ \\
Belum Bekerja & 63 orang & $24 \%$ \\
\hline Total & 260 orang & $100 \%$ \\
\hline Sul & &
\end{tabular}

Sumber: Hasil Olahan Data (2017)

\section{Pengujian Instrumen Penelitian}

\section{a. Uji Validitas}

Uji validitas dilakukan dengan metode Corrected Item Total Correlation. Dari output tersebut dapat diketahui nilai korelasi antara tiap pernyataan dengan skor total . Nilai korelasi ini dibandingkan dengan $r$ tabel. $r$ tabel dicari pada uji dua sisi pada taraf signifikansi 0,10 dan jumlah data $(\mathrm{n})=260$ atau $\mathrm{df}=\mathrm{n}-\mathrm{k}-1=260-3-1=256$, didapat $\mathrm{r}$ tabel 1,103, jika $r_{\text {hitung }}>r_{\text {tabel }}$ maka data tersebut dinyatakan valid dan sebaliknya. Dari hasil uji validitas menunjukkan untuk variabel kondisi mahasiswa, keterampilan dosen mengajar, lingkungan kampus dan motivasi belajar menunjukkan hasil $r_{\text {hitung }}>r_{\text {tabel }}$ sehingga dapat disimpulkan bahwa semua pernyataan untuk ke 4 variabel tersebut valid dan dapat digunakan untuk penelitian sehingga dapat dilanjutkan untuk dilakukan pengujian reliabilitas.

\section{Pengujian Reliabilitas}

Reliabilitas adalah indeks yang menunjukkan sejauh mana suatu alat pengukurdapat dipercaya ataudapat diandalkan.Bilasuatualat pengukur dipakai dua kaliataulebihuntukmengukurgejalayangsamadanhasilnyarelatifkonsisten,maka alatpengukurtersebut reliabel. Dengan katalainreliabilitasnya menunjukkan konsistensi. 
Apabila $r$ alpha dari masing-masing variabel lebih besar dari 0,60 maka semua pernyataan yang telah diuji untuk variabel kondisi mahasiswa, keterampilan dosen mengajar, lingkungan kampus dan motivasi belajar mahasiswa dinyatakan reliabel sehingga dapat dipergunakan dalam penelitian ini. Hasil uji reliabilitas menunjukkan alpha cronbach untuk variabel kondisi mahasiswa sebesar 0,909, untuk variabel keterampilan dosen mengajar sebesar 0,920, untuk variabel lingkungan kampus sebesar 0,882 dan untuk variabel motivasi belajar mahasiswa sebesar 0,807. Dengan demikian dapat dinyatakan semua variabel reliabel karena alpha cronbach lebih besar dari kriteria penilaian yaitu 0,60 .

\section{Analisis Regresi Linier Berganda}

Analisis ini digunakan untuk mengetahui pengaruh kondisi mahasiswa, keterampilan dosen mengajar, lingkungan kampus terhadap motivasi belajar mahasiswa . Selain itu juga digunakan untuk memprediksikan nilai variabel kondisi mahasiswa, keterampilan dosen mengajar dan lingkungan kampus apabila variabel motivasi belajar mahasiswa mengalami penurunan atau kenaikan, dan juga untuk mengetahui arah hubungan apakah berhubungan secara positif atau negatif. Analisis dilakukan dnegan bantuan program SPSS for windows.

Tabel 2. Hasil Regresi antara Variabel Kondisi Mahasiswa, Keterampilan Dosen Mengajar, Lingkungan Kampus terhadap Motivasi Belajar Mahasiswa

\begin{tabular}{|c|c|c|c|c|c|c|c|}
\hline \multirow[b]{2}{*}{ Model } & \multicolumn{2}{|c|}{$\begin{array}{l}\text { Unstandarized } \\
\text { Coefficients }\end{array}$} & \multirow{2}{*}{$\begin{array}{l}\text { Standardized } \\
\text { Coefficients } \\
\text { Beta }\end{array}$} & \multirow[b]{2}{*}{$\mathrm{t}$} & \multirow[b]{2}{*}{ Sig. } & \multirow{2}{*}{$\begin{array}{l}\text { Collinearity } \\
\text { Tolerance }\end{array}$} & \multirow{2}{*}{$\begin{array}{c}\text { Statistics } \\
\text { VIF }\end{array}$} \\
\hline & B & $\begin{array}{l}\text { Std. } \\
\text { Error }\end{array}$ & & & & & \\
\hline 1 (Constant) & 6,687 & 1,069 & & 6,255 &, 000 & & \\
\hline Kondisi Mahasiswa & ,200 &, 055 & ,343 & 3,609 & ,000 & ,295 & 3,384 \\
\hline $\begin{array}{l}\text { Keterampilan Dosen } \\
\text { Mengajar }\end{array}$ &, 057 &, 047 & 109 & 1,200 &, 231 &, 322 & 3,102 \\
\hline Lingkungan Kampus & ,078 & ,024 & ,194 & 3,218 & ,001 & ,739 & 1,353 \\
\hline
\end{tabular}

Tabel 7 memperlihatkan hasil regresi linier berganda yang menghasilkan persamaan: $\mathrm{Y}=6,687+0,200 \mathrm{X} 1+0,057 \mathrm{X} 2+0,078 \mathrm{X} 3+€$

Konstanta $=6,687$ artinya jika Kondisi Mahasiswa, Keterampilan Memgajar Dosen dan Lingkungan Kampus nilainya 0 maka Motivasi Belajar mahasiswa nilainya sebesar 6,687 .

Koefisien regresi variabel kondisi mahasiswa sebesar 0,200, artinya jika Kondisi Mahasiswa mengalami kenaikan satu satuan, maka Motivasi belajar akan mengalami 
peningkatan sebesar 0,200 satuan dengan asumsi variabel independen lainnya bernilai tetap

Koefisien regresi variabel keterampilan mengajar dosen sebesar 0,057, artinya jika keterampilan mengajar dosen mengalami kenaikan satu satuan, maka Motivasi belajar mahasiswa akan mengalami peningkatan sebesar 0,057 satuan dengan asumsi variabel independen lainnya bernilai tetap

Koefisien regresi variabel lingkungan kampus sebesar 0,078, artinya jika Lingkungan Kampus mengalami kenaikan satu satuan, maka Motivasi belajar mahasiswa akan mengalami peningkatan sebesar 0,078 satuan dengan asumsi variabel independen lainnya bernilai tetap

Dari ketiga variable tersebut, variable kondisi mahasiswa mempunyai pengaruh yang paling dominan terhahadap motivasi belajar mahasiswa. Hal ini dapat ditunjukkan dengan nilai koefisiennya yang paling tinggi baik pada Beta Unstandardized Coefficient yaitu sebesar 0,200.dan dari BetaStadardized Coefficientsebesar 0,055.

\section{Pengujian Hipotesis \\ Uji t-statistik}

Uji t digunakan untuk mengetahui apakah variabel independen secara parsial berpengaruh terhadap variabel dependen.

\section{Variabel Kondisi Mahasiswa}

H0: Kondisi mahasiswa secara parsial tidak berpengaruh terhadap motivasi belajar mahasiswa

H1: Kondisi mahasiswa secara parsial berpengaruh terhadap motivasi belajar mahasiswa Berdasarkan hasil uji $\mathrm{t}$ diperoleh $\mathrm{t}$ hitung 3,609 $>$ dari $\mathrm{t}$ tabel $=1,651$ dan nilai signifikansi sebesar 0,000 $<0,05$ yang artinya H0 ditolak dan H1 diterima berarti variabel Kondisi Mahasiswa secara individual berpengaruh signifikan terhadap Motivasi Belajar Mahasiswa. Nilai t hitung positif artinya semakin tinggi atau semakin baik kondisi mahasiswa maka semakin meningkat motivasi belajarnya.

\section{Variabel Keterampilan Mengajar Dosen}

H0: Keterampilan Mengajar Dosen secara parsial tidak berpengaruh terhadap motivasi belajar mahasiswa

H1: Keterampilan Mengajar Dosen secara parsial berpengaruh terhadap motivasi belajar mahasiswa

Berdasarkan hasil uji t diperoleh t hitung 1,200 < dari t tabel $=1,651$ dan nilai signifikansi sebesar 0,231 > 0,05 yang artinya H0 diterima dan H1 ditolak berarti 
variabel Keterampilan Mengajar Dosen secara individual tidak berpengaruh terhadap Motivasi Belajar Mahasiswa. Nilai t hitung positif artinya semakin tinggi atau semakin baik keterampilan mengajar dosen maka semakin meningkat motivasi belajar mahasiswa.

\section{Variabel Lingkungan Kampus}

H0: Lingkungan Kampus secara parsial tidak berpengaruh terhadap motivasi belajar mahasiswa

H1: Lingkungan Kampus secara parsial berpengaruh terhadap motivasi belajar mahasiswa

Berdasarkan hasil uji $\mathrm{t}$ diperoleh $\mathrm{t}$ hitung 3,609 $>$ dari $\mathrm{t}$ tabel $=1,651$ dan nilai signifikansi sebesar 0,000 $<0,05$ yang artinya H0 ditolak dan H1 diterima berarti variabel Kondisi Mahasiswa secara individual berpengaruh signifikan terhadap Motivasi Belajar Mahasiswa. Nilai t hitung positif artinya semakin tinggi atau semakin baik kondisi mahasiswa maka semakin meningkat motivasi belajarnya.

\section{Uji F-statistik}

Digunakan untuk menguji apakah variabel independen secara simultan berpengaruh terhadap variabel dependen.

H0: Kondisi Mahasiswa, Keterampilan Dosen mengajar dan Lingkungan Kampus tidak berpengaruh seacara simultan terhadap motivasi belajar

H1: Kondisi Mahasiswa, Keterampilan Dosen mengajar dan Lingkungan Kampus berpengaruh secara simultan terhadap motivasi belajar

Hasil uji $F$ menunjukkan $F_{\text {hitung }}$ adalah 39,308. Olehkarena $F_{\text {hitung }}>F_{\text {tabel }}=2,105$ $(\alpha=10 \%)$ dengan tingkat signifikansi 0,000, maka H0 ditolak atau H1 diterima,yang berarti Kondisi Mahasiswa, Keterampilan Dosen Mengajar, Lingkungan Kampus secara serempak berpengaruh terhadap Motivasi Belajar Mahasiswa.

\section{Uji $\mathbf{R}^{2}$ (Koefisien Determinasi)}

Koefisien determinasi digunakan untuk mengetahui persentase sumbangan pengaruh variabel Kondisi Mahasiswa, Keterampilan Dosen Mengajar, Lingkungan Kampus terhadap Motivasi Belajar Mahasiswa. Hasil analisis determinasi dapat dilihat pada output Model Summary. 


\section{Tabel 3. Model Summary}

Model Summary ${ }^{b}$

\begin{tabular}{lrrrr}
\hline Model & R & R Square & $\begin{array}{c}\text { Adjusted R } \\
\text { Square }\end{array}$ & \multicolumn{2}{c}{$\begin{array}{c}\text { Std. Error of the } \\
\text { Estimate }\end{array}$} \\
\hline 1 &, $562^{\mathrm{a}}$ &, 315 &, 307 & 1,799 \\
\hline
\end{tabular}

a. Predictors: (Constant), Lingkungan Kampus, Keterampilan Dosen

Mengajar, Kondisi Mahasiswa

b. Dependent Variable: Motivasi Belajar Mahasiswa

Dari tabel di atas, angka Adjusted $R$ square sebesar 0,307. Hal ini berarti 30,7\% motivasi belajar mahasiswa dipengaruhi oleh kondisi mahasiswa, keterampilan mengajar dosen dan lingkungan kampus. Sisanya sebesar 69,3\% dipengaruhi oleh variabel lain yang tidak dimasukkan dalam model penelitian ini.

\section{SIMPULAN DAN SARAN}

Berdasarkan pada hasil analisis data diperoleh hasil sebagai berikut: 1) hasil analisis linier berganda menunjukkan semua variabel independen (kondisi mahasiswa, keterampilan mengajar dosen dan lingkungan kampus) berpengaruh secara signifikan terhadap motivasi belajar mahasiswa, variabel kondisi mahasiswa berpengaruh lebih dominan dibandingkan variabel lain, 2) hasil uji t menunjukkan bahwa secara parsial variabel kondisi mahasiswa dan lingkungan kampus berpengaruh secara signifikan terhadap variabel motivasi belajar ,mahasiswa,sedangkan keterampilan mengajar dosen secara parsial tidak berpengaruh secara signifikan terhadap motivasi belajar mahasiswa 3) Hasil Uji F menunjukkan bahwa variabel kondisi mahasiswa, keterampilan mengajar dosen dan lingkungan kampus secara simultan/serempak berpengaruh terhadap variabel motivasi belajar mahasiswa, 4) Hasil Uji Adjusted $R$ square menunjukkan koefisien determinasi sebesar 0,307 atau 30,7\% variabel kondisi mahasiswa, keterampilan mengajar dosen dan lingkungan kampus mempengaruhi motivasi blajar mahasiswa.

Dari hasil penelitian ini disarankan bagi peneliti lanjutan dapat menambahkan variabel lain pada model penelitian ini. 


\section{DAFTAR PUSTAKA}

Dimyati dan Mudjiono.(2006). Belajar dan Perkembangan. Jakarta: PT Rineka Cipta.

Hastuti. (2010). Pengaruh Lingkungan Kampus Terhadap Motivasi Belajar Mahasiswa. Surabaya : Universitas Pelita Harapan Surabaya.

Miftahul Farihin. (2014). Pengaruh Kondisi Mahasiswa Dan Lingkungan Belajar Terhadap Motivasi Belajar Mahasiswa Program Studi Pendidikan Administrasi Perkantoran Fakultas Ekonomi Universitas Negeri Yogyakarta: Universitas Negeri Yogyakarta.

Mulyasa. (2004). Manajemen Berbasis Sekolah. Bandung: PT RemajaRosdakarya.

Oemar Hamalik. (2003). Proses Belajar Mengajar. Bandung: Bumi Aksara.

Sardiman. (2011). Interaksi \&Motivasi Belajar mengajar. Jakarta: Raja Grafindo Persada.

Sugiyono. (2003). Metode Penelitian Bisnis. Bandung: CV. Alfabeta.

Syaiful Bahri Djamarah. (2002). Strategi Belajar Mengajar. Jakarta: RinekaCipta.

Thursan Hakim. (2010). Belajar Secara Efektif. Jakarta. Pustaka Pembangunan Swadaya Nusantara. (2003). Undang-Undang Sistem Pendidikan Nasional 